Polymer Journal, Vol. 7, No. 3, pp 300-311 (1975)

\title{
Chlorinated Polyethylene. III. Relationships of Microstructure and Thermal Properties
}

\author{
Bienvenu-Magloire Quenum, Philippe Berticat, and Georges Vallet \\ Laboratoire de Chimie Macromoléculaire, Université Claude Bernard \\ 43, Boulevard du 11 Novembre 1918-69621 Villeurbanne, France.
}

(Received June 17, 1974)

\begin{abstract}
The thermal properties (viz., second-order transitions, melting points, dynamic and isothermal heat behaviour) of chlorinated polyethylene (CPE) samples are studied here. Thermomechanical analysis (TMA), differential thermal analysis (DTA), and thermogravimetric analysis (TGA) results are listed together to correlate the thermal properties and the microstructure of CPE samples, of various chlorine contents by weight, produced from thermal chlorinated or photochlorinated linear and branched polyethylene samples. The dehydrochlorination rate of a CPE sample is shown to be strongly dependent on its microtacticity up to a $56-61-\%$ chlorine content by weight value Beyond this $56-61-\% \mathrm{Cl}_{2}$ interval the microtacticity influence is screened by the steric hindrance introduced by the $\alpha_{\mathrm{I}}\left(-\mathrm{CH}_{2}-\mathrm{CHCl}-\mathrm{CCl}_{2}-\right.$ or $\left.-\mathrm{CHCl}-\mathrm{CHCl}-\mathrm{CCl}_{2}-\right), \alpha_{\mathrm{II}}-\mathrm{CHCl}-$ $\mathrm{C} \underline{\mathrm{HCl}}-\mathrm{CHCl}-$ or $\left.-\mathrm{CH}_{2}-\mathrm{CHCl}-\mathrm{CHCl}-\right)$, and $\beta_{\mathrm{II}}\left(-\mathrm{CHCl}-\mathrm{CH}_{2}-\mathrm{CCl}_{2}-\right)$ structures. At the saturation level (73-\% $\left.\mathrm{Cl}_{2}\right)$, the higher a $\mathrm{CPE}$ ratio, $\mathrm{nb} \mathrm{CHCl} / \mathrm{nb} \mathrm{CH}$, is, the lower is its maximum dehydrochlorination rate. When its ratio, $\mathrm{nb}^{2} \mathrm{CHCl} / \mathrm{nb} \mathrm{CH}_{2}$, is less than 4, a saturated (73\%) CPE sample has a unique global dehydrochlorination activation energy $\left(E_{\mathrm{a}}\right)$; when this ratio stands between 4 and 6 , there are two global dehydrochlorination $E_{\mathrm{a}}$. The structures which could be regarded as responsible for these different global $E_{\mathrm{a}}$ and the second-order transitions are specified.

KEY WORDS Chlorinated Polyethylene / Thermomechanical Analysis / Differential Thermal Analysis / Thermogravimetric Analysis / Second-Order Transitions / Maximum Dehydrochlorination Rate /
\end{abstract}

Very few studies have been published about the thermal properties of CPE. The first one, made by Oswald and $\mathrm{Kubu}^{1}$ dealt with glass-transition temperatures $\left(T_{\mathrm{g}}\right)$. Erä and Lindberg ${ }^{2}$ showed the effect of heat treatment on crystallinity. $\mathrm{Abu} \mathrm{Isa}^{3}$ studied the dechlorination mechanism and the effect of added antimony oxide on the rate of dehydrochlorination. Saglio, et al., ${ }^{4}$ studied the degradation of saturated (73\%) CPE and showed that fibers of saturated CPE can be used as a carbon fiber precursor.

The CPE samples used for the above studies were, generally, commercial ones supplied without the specific conditions of their preparation which are required ${ }^{5}$ to correlate microstructure and properties. In addition, their microstructural characterizations have been made only with infrared analysis, which is not sufficient.

Since we have prepared and characterized various CPE samples ${ }^{5-10}$ we will be able to cor- relate their microstructure and thermal properties in this paper.

In carbon backbone high polymers secondary transitions can be detected besides the main second-order transition, i.e., the glass-transition temperature $\left(T_{\mathrm{g}}\right)$, and the main first-order transition, i.e. the solid-liquid-transition or the melting temperature. They are:

(1) The secondary second-order transitions occuring, generally, at temperatures less than $T_{\mathrm{g}}$. They are related to the motion of short segments of the polymer's backbone (viz., branchings, substituants, "crankshaft" or "kink" mechanisms ${ }^{11,12}$ ) related to motions in the amorphous or crystalline phase.

(2) The secondary first-order transition or crystal-crystal transition which involves changes of crystalline forms. We will not take into account this secondary first-order transition because the crystallinity of the polyethylene is rapidly 
reduced as the chlorination proceeds.

\section{EXPERIMENTAL}

\section{Materials}

Two kinds of CPE samples have been employed:

Those of chlorine contents by weight less than 73-\% $\mathrm{Cl}_{2}$ : i.e., branched polyethylene samples photochlorinated at $20^{\circ} \mathrm{C}$ in 1,1,2,2-tetrachloroethane (TCE) (type Ia); branched polyethylene samples thermally chlorinated at $90^{\circ} \mathrm{C}$ in TCE (type $\mathrm{Ib}$ ); linear polyethylene samples thermally chlorinated at $110^{\circ} \mathrm{C}$ in TCE (type Ic). ${ }^{5}$

Those chlorinated at saturation level $\left(73-\% \mathrm{Cl}_{2}\right)$ : i.e., branched polyethylene samples (type IIa) and linear polyethylene samples (type $\mathrm{IIa}^{\prime}$ ) photochlorinated at $20^{\circ} \mathrm{C}$ in carbon tetrachloride $\left(\mathrm{CCl}_{4}\right)$ during 4-6-8 $\mathrm{hr} ;{ }^{7}$ branched polyethylene samples (type IIb) and linear polyethylene samples (type $\mathrm{IIb}^{\prime}$ )photochlorinated during $4 \mathrm{hr}$ at $20^{\circ} \mathrm{C}$; $40^{\circ} \mathrm{C} ; 60^{\circ} \mathrm{C}^{8}$ in $\mathrm{CCl}_{4}$.

\section{Second-Order Transitions}

The Dupont 942 Thermomechanical Analyser (942 TMA), coupled with the 990 Dupont Recorder was used to detect the second-order transitions of the CPE samples of type I. The experimental samples were the CPE-films describes previously. ${ }^{6}$ The tension-probe technique was used to record the changes of the elastic modulus of the CPE-film under a load, as a function of rising temperature. This technique is accurate only if the applied load does not cause any creep of the experimental sample in the time-frame of the experiment, i.e., in the temperature interval investigated. For all the measurements the experimental samples were $13 \mathrm{~mm}$ long (between two cleaved lead balls) and $2 \mathrm{~mm}$ wide; the applied load was $2 \mathrm{~g}$ and the heating rate was $5^{\circ} \mathrm{C} /$ min from a $40^{\circ} \mathrm{C}$ starting temperature.

\section{Melting Temperatures}

The Dupont 990 Thermal Analyser, coupled with the "DSC cell," was used to detect the melting points of the CPE samples of type I. Quantities of 5-10 $\mathrm{mg}$ of the powdered sampled were used. The heating rate was $10^{\circ} \mathrm{C} / \mathrm{min}$ from room temperature $\left(23^{\circ} \mathrm{C}\right)$. All the measurements were conducted in helium atmosphere.

\section{Thermogravimetric Studies}

A Cahn electrobalance Model R-H transformed into a TGA-instrument was used (Figure 1).

The glass wares were made from quartz. Each oven had an electric power of $1100 \mathrm{~W}$. The temperature-regulation device was a Stanton

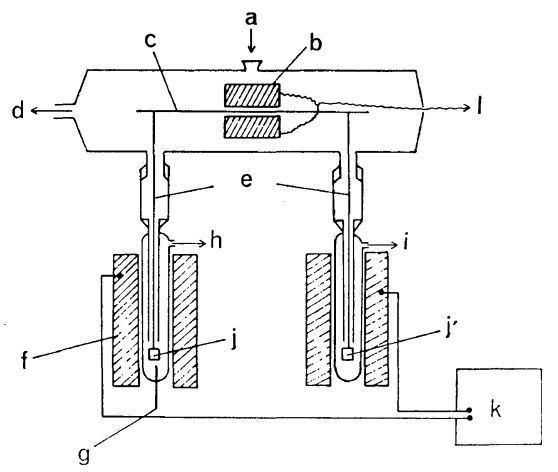

Figure 1. TGA apparatus: a, inert gas inlet; b, magnet; c, beam; d, vacuum system; e, hanging; $\mathrm{f}$, oven; $\mathrm{g}$, measurement thermocouple; $\mathrm{h}$, gas outlet; $i$, inert gas outlet; $j$, sample holder; $\mathrm{j}^{\prime}$, reference sample holder; $\mathrm{k}$, regulation system; 1 , recorder device.

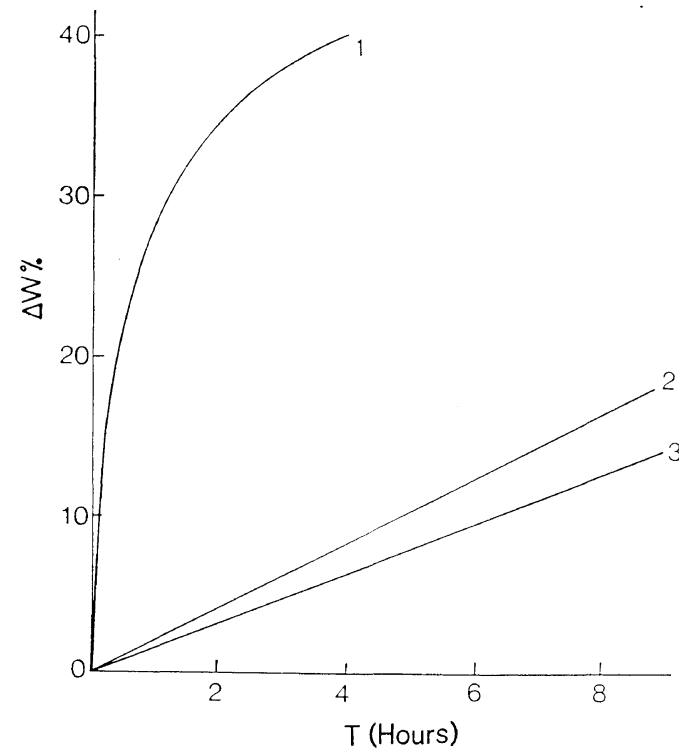

Figure 2. Isothermal $\left(235^{\circ} \mathrm{C}\right) \mathrm{TGA}$. Influence of the molecular-weight distribution (MWD) of a 73-\% CPE sample upon its weight-loss magnitude: 1 , lowest number-average molecular weight, $\mathbf{L} \bar{M}_{n}$, $6000 ; 2$ medium number-average molecular weight, $\mathrm{M} \bar{M}_{n}, 15000$; (3) highest number-average molecular weight, $\mathrm{H} \bar{M}_{n}, 50000$. 
redcroft's model; the recorder was a Kipp-Zonen Model BD-5.

We used the TGA dynamic method, i.e., the recording of the weight loss as the temperature is raised at a constant rate $\left(2^{\circ} \mathrm{C} / \mathrm{min}\right)$, to study the thermal behaviour of all the CPE samples (types I and II) over the $180^{\circ} \mathrm{C}-500^{\circ} \mathrm{C}$ interval. A Cahn Time-Derivative Computer Model MARK II, coupled with the TGA apparatus, was used to record the degradation rate.

The global activation energies $\left(E_{\mathrm{a}}\right)$ of the dehydrochlorination process have been calculated for the CPE samples of type II, viz., those chlorinated to the saturation level $\left(73-\% \mathrm{Cl}_{2}\right)$ by using the isothermal method. ${ }^{13}$ The polymeric chains' breakages occurring during the chlorination process could be enhanced if the chlorination time exceeds the minimum time necessary to obtain the saturation level. ${ }^{5,7}$

Figure 2 shows the influence of the molecular weight of a saturated $\left(73-\% \mathrm{Cl}_{2}\right) \mathrm{CPE}$ sample upon its weight-loss magnitude in an isothermal process; the fraction of the lowest number-average molecular weight $\left(\mathrm{L} \bar{M}_{n}\right)$ is rapidly degraded. Thus, to have reproductible runs and comparative results it is necessary to use homogeneous samples. All the experimental CPE samples of type II used in the isothermal process were fractions of the highest number-average molecular weight $\left(H \bar{M}_{n}\right)$ obtained by fractionation of the initial samples in a 70/30 mixture of tetrahydrofuran and methyl alcohol at room temperature. ${ }^{7}$

For each experiment, isothermal or dynamic, $20 \mathrm{mg}$ of powdered CPE sample were used. All the experiments were conducted in nitrogen atmosphere; the rate-flow of the gas through the sample and the reference tubes (Figure 1) was $6 \mathrm{l} / \mathrm{hr}$. The heating rate in the dynamic method was $2^{\circ} \mathrm{C} / \mathrm{min}$. These experimental conditions which permit reproductible runs, matched those advocated by Wendlandt, ${ }^{13}$ Guyot and Bert. ${ }^{14}$

\section{RESULTS AND DISCUSSION}

Two main theories have been established to explain the second-order transitions of polymers and particularly the glass transition: a kinetic based one ${ }^{12}$ and a thermodynamical one. ${ }^{15}$ In the following discussion we will follow the kinetic theory.

\section{Melting Points and Second-Order Transitions}

In Table I are listed the results obtained with the DTA experiments; three melting temperatures are reported: $T_{\mathrm{A}}$ is related to the starting of the melting process and $T_{\mathrm{C}}$ to its end, i.e., when the disruption of the polyethylene's crystallities is completed. Many scientists use $T_{\mathrm{f}_{\mathrm{m}}}$, the temperature at the thermogram-top (Figure 3), to characterize fusion. This $T_{\mathrm{f}_{\mathrm{m}}}$-temperature can be related to the average statistical thickness of the crystallites if the thermogram areas, on each side of the $T_{\mathrm{f}_{\mathrm{m}}}$-vertical-line, are symmetrical.

When the thermal chlorination proceeds, the crystallinity of the polyethylene samples (branched or linear) is rapidly destroyed (Table I); the numerous $-\mathrm{CCl}_{2}-$ units appearing during the first chlorination step ${ }^{5}$ can be regarded as responsible for this. But in the photochlorination process, the CPE samples keep some crystallinity up to a high chlorine-content value by weight; the crystallites disappearance is completed only beyound the $67.5-\%$ chlorine content value, as proved by dynamic mechanical properties studies; the 67.5-73-\% photochlorinated CPE samples are amorphous ones, although they are hard and brittle owing to the presence of dichloro and trichloroethylene units. ${ }^{10}$

In Table II are listed the Dupont 942 TMA results (second-order transitions). The asterisked transitions stand between the $T_{\mathrm{A}}$ and the $T_{\mathrm{C}}$ (Table I) of the CPE samples and can be related to the motions of short segments of the polymeric chains in the CPE crystalline phase. The

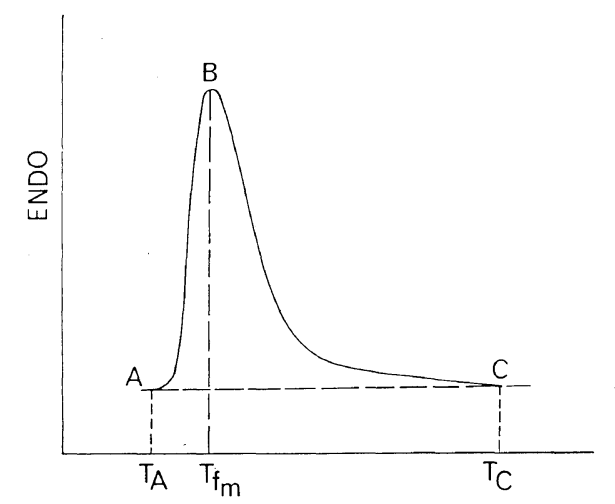

Figure 3. Thermogram of the $6-\% \mathrm{Cl}_{2}$ linear $\mathrm{CPE}$ sample. 
Table I. Melting points of the CPE samples ${ }^{a}$

\begin{tabular}{|c|c|c|c|c|c|c|c|c|c|c|c|c|c|c|}
\hline \multicolumn{5}{|c|}{$\begin{array}{l}\text { Type Ia. LDPE photochlorinated } \\
\text { at } 20^{\circ} \mathrm{C} \text { in TCE }\end{array}$} & \multicolumn{5}{|c|}{$\begin{array}{l}\text { Type Ib. LDPE thermalchlorin- } \\
\text { ated at } 90^{\circ} \text { in TCE }\end{array}$} & \multicolumn{5}{|c|}{$\begin{array}{l}\text { Type Ic. HDPE thermalchlorinated } \\
\text { at } 110^{\circ} \mathrm{C} \text { in TCE }\end{array}$} \\
\hline $\begin{array}{l}\mathrm{T}-\% \\
\mathrm{Cl}_{2}\end{array}$ & $\begin{array}{l}T_{\mathrm{A}}, \\
{ }^{\circ} \mathrm{C}\end{array}$ & $T_{\mathrm{f}_{\mathrm{m}}}$ & ${ }^{T_{\mathrm{C}}}$ & $\begin{array}{r}\Delta H \\
\mathrm{cal} / \mathrm{g}\end{array}$ & $\begin{array}{l}T-\% \\
\mathrm{Cl}_{2}\end{array}$ & $\begin{array}{l}T_{\mathrm{A}}, \\
{ }^{\circ} \mathrm{C}\end{array}$ & $T_{\mathrm{f}_{\mathrm{m}}}$, & $\begin{array}{l}T_{\mathrm{C}}, \\
{ }^{\circ} \mathrm{C}\end{array}$ & $\begin{array}{c}\Delta H \\
\mathrm{cal} / \mathrm{g}\end{array}$ & $\begin{array}{l}T-\% \\
\mathrm{Cl}_{2}\end{array}$ & $\begin{array}{l}T_{\mathrm{A}}, \\
{ }^{\circ} \mathrm{C}\end{array}$ & $T_{\mathrm{f}_{\mathrm{m}}}$ & $\begin{array}{l}T_{\mathrm{C}}, \\
{ }^{\circ} \mathrm{C}\end{array}$ & $\begin{array}{l}\Delta H \\
\mathrm{cal} / \mathrm{g}\end{array}$ \\
\hline 19.5 & 69 & 101 & 112 & 14.75 & 24 & 50 & 57 & 77 & 8 & 6 & 78.5 & 81 & 5 & 1 \\
\hline 46 & 82 & 105 & 112 & 11.6 & 3 & 32.5 & $\left.\begin{array}{l}41 \\
61 \\
73\end{array}\right\}$ & 86 & - & 41 & - & - & - & - \\
\hline 55 & 86 & 88 & 112 & 3.2 & 54.5 & - & - & - & - & 56 & - & - & - & - \\
\hline 60.5 & 65.5 & $\left.\begin{array}{r}82 \\
100\end{array}\right\}$ & 100 & - & 61.5 & - & - & - & - & 61.7 & - & - & - & - \\
\hline 67. & - & - & - & - & 65 & - & - & - & - & 64 & - & - & - & - \\
\hline 68.4 & - & - & - & - & - & - & - & - & - & 67 & - & - & - & - \\
\hline
\end{tabular}

a The dashed lines indicate that the CPE sample did not show any melting point in the $25-180^{\circ} \mathrm{C}$ range.

Initial LDPE $T_{\mathrm{f}_{\mathrm{m}}}, 110^{\circ} \mathrm{C} ; \Delta H, 32.8 \mathrm{cal} / \mathrm{g}$.

Initial HDPE $T_{\mathrm{f}_{\mathrm{m}}}, 134^{\circ} \mathrm{C} ; \Delta H, 58 \mathrm{cal} / \mathrm{g}$.

$T_{\mathrm{A}}$, melting-process starting; $T_{\mathrm{f}_{\mathrm{m}}}$, temperature at the thermogram-top; $T_{\mathrm{C}}$, melting-process end.

The thermograms of the $60.5-\% \mathrm{Cl}_{2}$ photochlorinated $\mathrm{CPE}$ sample and the $33-\% \mathrm{Cl}_{2}$ thermal chlorinated CPE sample show many $T_{\mathrm{f}_{\mathrm{m}}}$; in such cases the calculation of the $\Delta H$ is not easy.

temperatures of nearly all these asterisked transitions are in close agreement with the temperatures of the $\alpha$-relaxation peak of the photochlorinated CPE samples. ${ }^{10}$

The other transitions i.e., the non-asterisked ones, can be easily related to the various structures revealed by the microstructural nuclearmagnetic-resonance (NMR) study. ${ }^{5,9}$

In the thermal-chlorination process, between $\varepsilon-\% \mathrm{Cl}_{2}$ and $24-\% \mathrm{Cl}_{2}$, the chlorination mechanism is not yet a random one. The $-\mathrm{CCl}_{2}-$ groups of the structures, such as:

$$
\begin{aligned}
& \sim\left(-\mathrm{CH}_{2}-\mathrm{CH}_{2}-\right)_{4}-\mathrm{CCl}_{2}-\mathrm{CH}_{2}-\mathrm{CCl}_{2}- \\
& -\left(\mathrm{CH}_{2}-\mathrm{CH}_{2}-\right)_{4} \cdots
\end{aligned}
$$

or

$$
\begin{aligned}
& \sim\left(-\mathrm{CH}_{2}-\mathrm{CH}_{2}-\right)_{4}-\mathrm{CCl}_{2}-\mathrm{CH}_{2}-\mathrm{CH}_{2}- \\
& \mathrm{CCl}_{2}-\left(\mathrm{CH}_{2}-\mathrm{CH}_{2}-\right)_{4} \sim
\end{aligned}
$$

are responsible for almost the whole chlorine content value ${ }^{5}$ and the thermal CPE samples still keep crystallinity. When the poly(vinyl chloride) (PVC) triads $\alpha_{\mathrm{III}}\left(-\mathrm{CH}_{2}-\mathrm{CHCl}-\mathrm{CH}_{2}-\right)$ and $\beta_{\text {III }}$ (- $\mathrm{CHCl}-\mathrm{CH}_{2}-\mathrm{CHCl}-$ ) appear from the 24-\% $\mathrm{Cl}_{2}$ value) the chlorination mechanism becomes a random one, ${ }^{5}$ which destroys the crystallinity of the thermal CPE samples. The numerous $-\mathrm{CCl}_{2}-$ units along with the few
- $\mathrm{CHCl}$ - units behave like a plasticizer, which lowers the second-order transition temperature. This effect is maximum in the range of the 3341-\% chlorine content and the 33-41-\% CPE samples are similar to elastomers. ${ }^{10}$

Beyond the 33-41-\% $\mathrm{Cl}_{2}$ range $\mathrm{PVC}$ sequences increase and the temperatures of the second-order transitions rise.

When the PVC sequences reach their maximum length, there is an important difference between the 56-\% thermal-chlorinated linear polyethylene sample and the 61.5-\% thermal-chlorinated branched-polyethylene sample. The latter has more $\beta^{\prime}{ }_{\text {IV }}$ structure (mono or dichloropropane or butane); otherwise the $61.5-\%$ thermally chlorinated branched polyethylene sample has PVC sequences shorter than those of the 56- $\%$ thermally chlorinated linear polyethylene sample. ${ }^{5}$ Thus, at the proper temperature, those short PVC sequences will go easily into motion along with the $\beta^{\prime}{ }_{\text {IV }}$ structures and consequently the $61.5-\%$ thermal (branched) CPE sample has a unique second-order transition. On the contrary, the long PVC sequences of the 56-\% thermal (linear) CPE sample will not go easily into motion a long with the $\beta^{\prime}{ }_{\text {IV }}$ structures; the two entities, the PVC sequences and the $\beta^{\prime}{ }_{\text {IV }}$ structures, will each have its second-order transition 
temperature, with that of the $\beta_{\text {IV }}^{\prime}$ structures being lower. As the $\beta_{\mathrm{II}}\left(-\mathrm{CHCl}-\mathrm{CH}_{2}-\mathrm{CHCl}-\right.$ ) structures neighboring with $\mathrm{CHCl}$ units are already present in large amounts in the 56-\% thermal (linear) CPE sample, their second-order transition temperature will take place at a temperature higher than that of the PVC sequences.

In the photochlorination process, when the reaction is carried out in a suspension medium $\left(20^{\circ} \mathrm{C}\right)$, the radical substitution of the hydrogen atoms by chlorine atoms starts in the amorphous phase of the polymer and vinyl units first appear. ${ }^{5}$ These vinyl units are responsible for a unique second-order transition up to about the

Table II. Second-order transitions of the CPE samples $^{a}$

Type Ia. LDPE photochlorinated at $20^{\circ} \mathrm{C}$ in $\mathrm{TCE}^{\mathrm{b}}$

\begin{tabular}{|c|c|c|c|c|c|}
\hline \multirow{2}{*}{$\begin{array}{l}T-\% \\
\mathrm{Cl}_{2}\end{array}$} & \multirow{2}{*}{$\frac{\mathrm{CHCl}}{\mathrm{CH}_{2}}$} & \multirow{2}{*}{$\overline{\mathrm{DP}_{n}}$} & \multicolumn{3}{|c|}{ Transition } \\
\hline & & & 1 st & 2nd & $3 \mathrm{rd}$ \\
\hline 16 & 0.111 & 1270 & $36^{\circ} \mathrm{C}$ & $103^{\circ} \mathrm{C}^{*}$ & - \\
\hline 19.5 & - & - & $33^{\circ} \mathrm{C}$ & $96^{\circ} \mathrm{C}^{*}$ & - \\
\hline 46 & 0.266 & 1320 & $48^{\circ} \mathrm{C}$ & $71^{\circ} \mathrm{C}$ & $90^{\circ} \mathrm{C}^{*}$ \\
\hline 55 & 0.316 & 2750 & $66^{\circ} \mathrm{C}$ & $78^{\circ} \mathrm{C}$ & - \\
\hline 60.5 & 0.9 & 2930 & $76^{\circ} \mathrm{C}$ & $88^{\circ} \mathrm{C}$ & - \\
\hline 67.5 & 1.88 & 2220 & $76^{\circ} \mathrm{C}$ & $108^{\circ} \mathrm{C}$ & $148^{\circ} \mathrm{C}$ \\
\hline 68.4 & 1.98 & 700 & $78^{\circ} \mathrm{C}$ & $137^{\circ} \mathrm{C}$ & $150^{\circ} \mathrm{C}$ \\
\hline
\end{tabular}

Type Ib. LDPE thermal-chlorinated at $90^{\circ} \mathrm{C}$ in $\mathrm{TCE}^{\mathrm{b}}$

\begin{tabular}{lcrrcc}
\hline 24 & $\varepsilon$ & 1000 & $32^{\circ} \mathrm{C}$ & $56^{\circ} \mathrm{C}^{*}$ & - \\
33 & 0.07 & 1580 & $-12^{\circ} \mathrm{C}$ & - & - \\
54.5 & 0.38 & 1760 & $60^{\circ} \mathrm{C}$ & - & - \\
61.5 & 0.44 & 1310 & $55^{\circ} \mathrm{C}$ & - & - \\
65 & 1.31 & 1065 & $58^{\circ} \mathrm{C}$ & $70^{\circ} \mathrm{C}$ & $102^{\circ} \mathrm{C}$
\end{tabular}

Type Ic. HDPE thermal-chlorinated at $110^{\circ} \mathrm{C}$ in $\mathrm{TCE}^{\mathrm{b}}$

\begin{tabular}{llrrrr}
\hline 6 & \multicolumn{1}{c}{$\varepsilon$} & 1500 & $10^{\circ} \mathrm{C}$ & $104^{\circ} \mathrm{C} *$ & - \\
41 & 0.114 & 1810 & $0^{\circ} \mathrm{C}$ & - & - \\
56 & 0.483 & 1360 & $52^{\circ} \mathrm{C}$ & $68^{\circ} \mathrm{C}$ & $90^{\circ} \mathrm{C}$ \\
61.7 & 1.27 & 1000 & $76^{\circ} \mathrm{C}$ & $94^{\circ} \mathrm{C}$ & $130^{\circ} \mathrm{C}$ \\
64 & 1.975 & 595 & $80^{\circ} \mathrm{C}$ & $128^{\circ} \mathrm{C}$ & $160^{\circ} \mathrm{C}$ \\
67 & 2.66 & 328 & $75^{\circ} \mathrm{C}$ & $160^{\circ} \mathrm{C}$ & $176^{\circ} \mathrm{C}$ \\
\hline
\end{tabular}

a The starting temperature was $-40^{\circ} \mathrm{C}$; the initial HDPE has a unique second-order transition temperature at $12^{\circ} \mathrm{C}$, and the initial LDPE one at $-20^{\circ} \mathrm{C}$.

b TCE, 1,1,2,2-tetrachloroethane.
20-\% chlorine content. From this value PVDC triads or tetrads $\left(-\mathrm{CCl}_{2}-\mathrm{CH}_{2}-\mathrm{CCl}_{2}-\right.$ or $-\mathrm{CCl}_{2}-\mathrm{CH}_{2}-\mathrm{CH}_{2}-\mathrm{CCl}_{2}-$ ) appear randomly in the photochlorinated CPE chains. ${ }^{5}$ When these PVDC units reach their maximum proportion the photochlorinated CPE samples have two secondorder transitions. The short PVC sequences surrounded by a PVDC triad or tetrad can be regarded as responsible for the second-order transition taking place at the lower temperature; the other second-order transition can be attributed to the motion of the long PVC sequences.

In the thermal chlorination process or in the photochlorination one, when the reaction proceeds beyond the $56-61.5-\% \mathrm{Cl}_{2}$ range, the $\alpha_{\mathrm{II}}$ $\left(-\mathrm{CHCl}-\mathrm{CHCl}-\mathrm{CHCl}-\right.$ or $-\mathrm{CH}_{2}-\mathrm{CHCl}-$ $\mathrm{CH}_{2}-$ ) and the $\alpha_{\mathrm{I}}\left(-\mathrm{CHCl}-\mathrm{CHCl}-\mathrm{CCl}_{2}-\right.$ or $-\mathrm{CH}_{2}-\mathrm{CHCl}-\mathrm{CCl}_{2}-$ ) structures which appear stiffen the CPE chains; ${ }^{10}$ their second-order transition temperatures are distinct and higher than those of the previously described structures.

To sum up, we have reported in Tables Va, $\mathrm{Vb}$ and $\mathrm{Vc}$ the structures which can be regarded are responsible for the second-order transitions. During the discussion we have not named any of the second-order transitions of CPE sample a glass transition $\left(T_{\mathrm{g}}\right)$, since the Dupont 942 TMA method is only a qualitative one. But the second-order transitions revealed by the TMA method and those revealed by the dynamic mechanical properties' studies, carried out with the Rheovibron, ${ }^{10}$ appear at almost the same temperatures; thus it is easy by listing together the two different results and by defining the $T_{g}$ as the temperature for which the complex modulus decreases sharply to identify the $T_{\mathrm{g}}$. These are plus-marked in Tables V.

In our previous study ${ }^{10}$ we showed that between the 46-60.5\% chlorine-content range (for photochlorinated CPE samples) the $\alpha$-peak (motions in the crystalline phase of the CPE sample) and the $\beta$-peak (vinyl sequences motion) stand at the same temperature. In this chlorinecontent interval, the disruption of the crystallites of the polyethylene is high although not yet completed (see Table I). It is important to notice that, in spite of the difference in technique, the Dupont 942 TMA method reveals a similar behavior for the 46-60.6-\% photochlorinated CPE 
samples (e.g., the 55-\% CPE samples in Table $\mathrm{Va}$ and the 49-\% photochlorinated CPE sample in our previous study ${ }^{10}$ ).

\section{Dynamic TGA Experiments}

Figures 4 and 6 show the weight loss of the photochlorinated (type Ia) and thermally chlorinated (type Ib) branched polyethylene samples in dynamic TGA experiments. Figure 5 and 7 represent the degradation rates corresponding to the curves in Figures 4 and 6.

As can be seen on Figures 5 and 7 the plots of the degradation rates $v s$. the chlorine contents by weight reveal two peaks between $180^{\circ} \mathrm{C}$ and $500^{\circ} \mathrm{C}$, depending on the chlorination degree of the CPE samples.

The first peak stands within the $262-272^{\circ} \mathrm{C}$ interval for the photochlorinated CPE sample (type Ia) and within the $266-288^{\circ} \mathrm{C}$ interval for the thermal-chlorinated CPE samples (type $\mathrm{Ib}$ ). Figures 4,6 , and 11 show that, up to $300^{\circ} \mathrm{C}$, the hydrochloric acid evolution is responsible for the whole amount of the weight loss of the CPE samples. Therefore we can assign the first peak to the maximum dehydrochlorination rate of the chlorinated sequences present in the CPE chains.

The second peak stands within $400-420^{\circ} \mathrm{C}$ samples (type Ia) and within $400-418^{\circ} \mathrm{C}$ for the

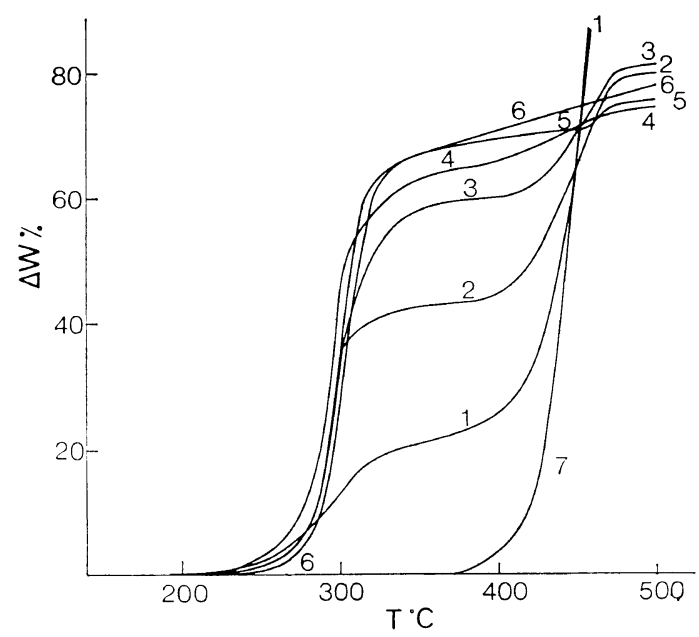

Figure 4. Dynamic TGA $\left(2^{\circ} \mathrm{C} / \mathrm{min}\right)$ of branched polyethylene samples photochlorinated at $20^{\circ} \mathrm{C}$ in 1,1,2,2-tetrachloroethane (TCE): $1,16-\% \mathrm{Cl}_{2} ; 2$, $46-\% \mathrm{Cl}_{2} ; 3,55-\% \mathrm{Cl}_{2} ; 4,60.5-\% \mathrm{Cl}_{2} ; 5,67.5-\%$ $\mathrm{Cl}_{2} ; 6,73-\% \mathrm{Cl}_{2} ; 7$, initial LDPE.

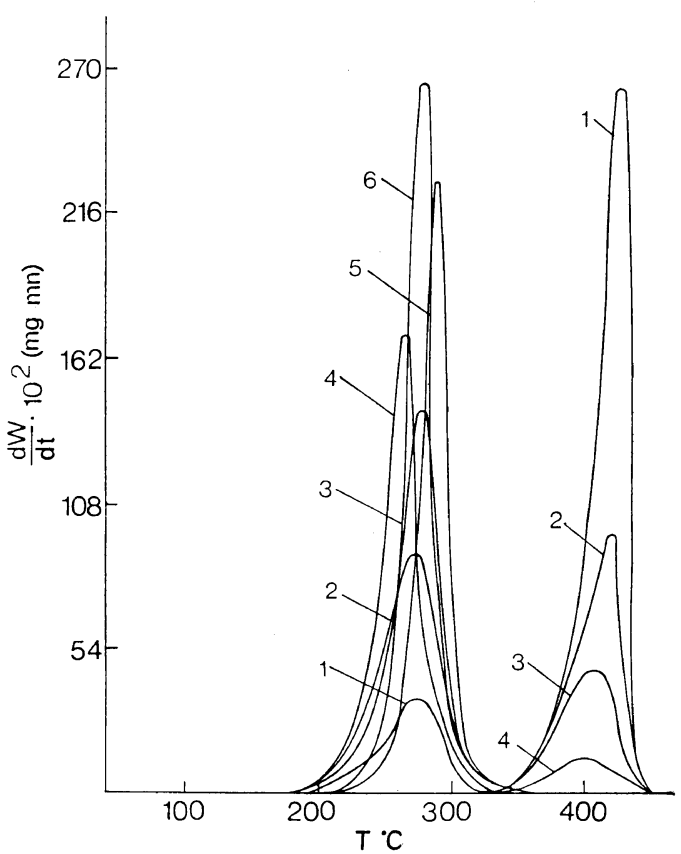

Figure 5. Degradation rates of branched polyethylene samples photochlorinated $\left(20^{\circ} \mathrm{C}\right)$ in $1,1,2,2-$ tetrachloroethane (TCE): $1,16-\% \mathrm{Cl}_{2} ; 2,46-\% \mathrm{Cl}_{2}$; $3,55-\% \mathrm{Cl}_{2} ; 4,60.5-\mathrm{Cl}_{2} ; 5,67.5-\% \mathrm{Cl}_{2} ; 6,73-\% \mathrm{Cl}_{2}$.

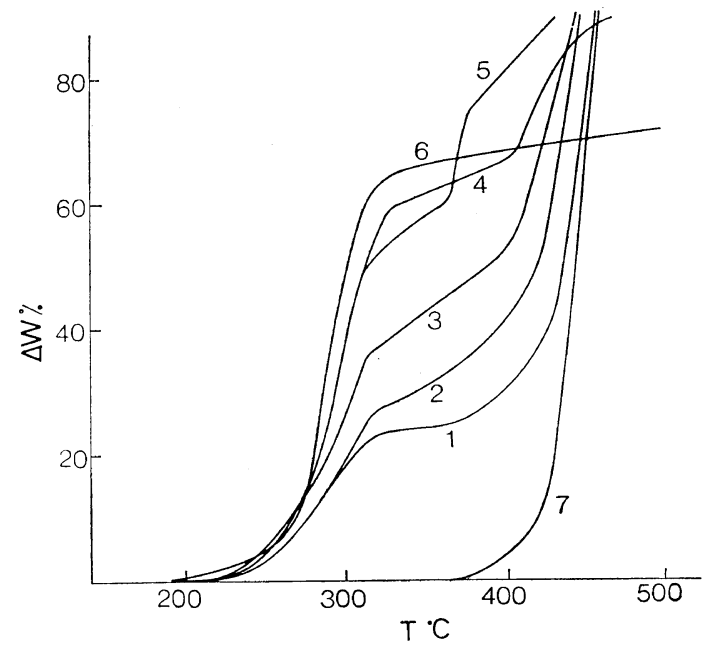

Figure 6. Dynamic TGA $\left(2^{\circ} \mathrm{C} / \mathrm{min}\right)$ of branched polyethylene samples thermally chlorinated $\left(90^{\circ} \mathrm{C}\right)$ in 1,1,2,2-tetrachloroethane (TCE): $1,24-\% \mathrm{Cl}_{2}$; $2,33-\% \mathrm{Cl}_{2} ; 3,38-\% \mathrm{Cl}_{2} ; 4,54.5-\% \mathrm{Cl}_{2} ; 5,61.5-\%$ $\mathrm{Cl}_{2} ; 6,65-\% \mathrm{Cl}_{2} ; 7$, initial LDPE. 


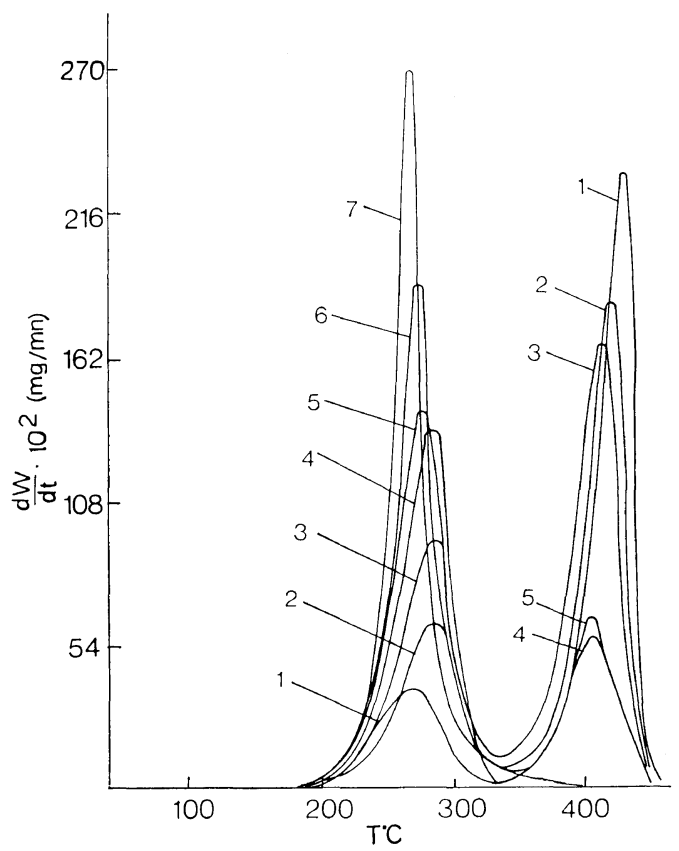

Figure 7. Degradation rates of branched polyethylene samples thermally chlorinated $\left(90^{\circ} \mathrm{C}\right)$ in $1,1,2,2$ tetrachloroethane (TCE): $1,24-\% \mathrm{Cl}_{2} ; 2,33-\% \mathrm{Cl}_{2}$; 3, 38-\% $\mathrm{Cl}_{2} ; 4,54.5-\% \mathrm{Cl}_{2} ; 5,61.5-\% \mathrm{Cl}_{2} ; 6,63-\%$ $\mathrm{Cl}_{2} ; 7,65-\% \mathrm{Cl}_{2}$.

thermal CPE samples (type Ib). By comparison to the parent-polymer's behavior in that range of temperature, one can attribute this second peak to the maximum degradation rate corresponding to the evolution of volatile products such as hydrogen gas methane, ethylene, and poorly chlorinated olefines. One must notice that this peak disappears when the CPE sample's chlorine content is higher than $60.5 \%$ (type Ia) or $61.5 \%$ (type Ib), i.e., when the polyethylene sequences and the $\beta^{\prime}{ }_{\text {IV }}$ structures (monochloro and dichloropropane or butane) have disappeared. ${ }^{5}$

Figure 8 represents the plot of the maximum dehydrochlorination rate (viz., the first peak value) of the photochlorinated CPE samples (type Ia) against their syndiotacticity-index, $S .{ }^{5,6}$

The plots of the maximum dehydrochlorination rate of the CPE samples (type Ia and type Ib) vs. the ratio, $\mathrm{nbCHCl} / \mathrm{nb} \mathrm{CH}_{2}$, are represented in Figure 9.

These two figures ( 8 and 9) permit us to show the influence of the microtacticity and the molec- ular microstructure of CPE samples upon the magnitudes of their dehydrochlorination rates.

As can be seen in Figure 8, up to the 60.5-\% chlorine-content value, i.e., till the PVC sequences reach their maximum length, ${ }^{5}$ a slight increase of the syndiotacticity-index, $S$, leads to a large increase of the maximum dehydrochlorination rate $\left(\Delta_{\mathrm{r}}(\mathrm{HCl}) / \Delta S \simeq 800\right)$. When the $\mathrm{PVC}$ sequences decrease, from the $60.5-\%$ chlorine-content value, i.e., when the $\alpha_{\mathrm{II}}(-\mathrm{CHCl}-\mathrm{CHCl}-\mathrm{CHCl}-$ or $\left.-\mathrm{CH}_{2}-\mathrm{CHCl}-\mathrm{CHCl}-\right)$ and $\beta_{\mathrm{II}}(-\mathrm{CHCl}-$ $\mathrm{CH}_{2}-\mathrm{CCl}_{2}-$ ) structures appear, ${ }^{5}$ a large increase of the syndiotacticity-index, $S$, leads to only a slight increase of the maximum dehydrochlorination rate $\left(\Delta_{\mathrm{r}}(\mathrm{HCl}) / S \simeq 80\right)$.

The first behavior, i.e., the large increase of the maximum dehydrochlorination rate $v s$. a slight increase of the syndiotacticity-index, depends on the microtacticity. Indeed, between $\varepsilon-\%$ and $60.5-\% \mathrm{Cl}_{2}$, the PVC sequences increase and the polymeric chains are freed from high steric hindrance; ${ }^{5}$ thus the dehydrochlorination occuring on the long PVC syndiotactic sequences TTTT can be have like a "zip" mechanism. ${ }^{16}$

The second behavior, i.e., the slight increase of the maximum dehydrochlorination rate $i s$. a large increase of the syndiotacticity, depends on the molecular microstructure.

As can be seen in Figure 9, the maximum dehydrochlorination rate decreases when the $\alpha_{I I}$

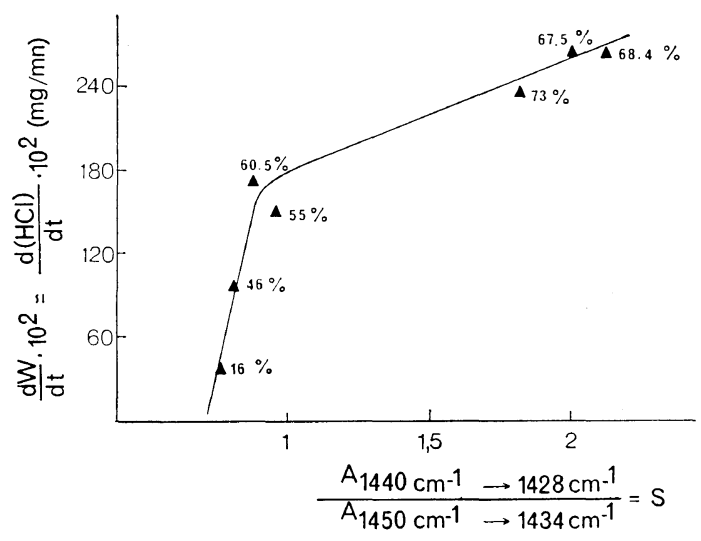

Figure 8. Maximum degradation rate $v s$. syndiotacticity-index for branched polyethylene samples photochlorinated $\left(20^{\circ} \mathrm{C}\right)$ in 1,1,2,2-tetrachloroethane (TCE). The percentage values represent the chlorine content by weight. 


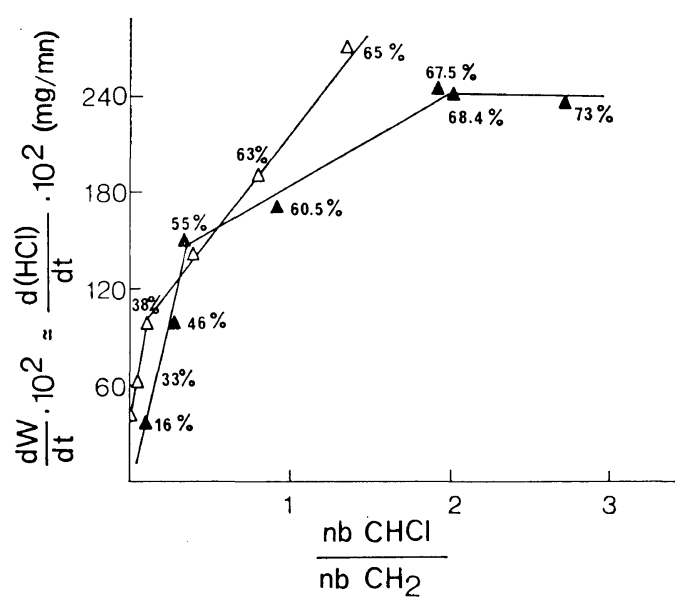

Figure 9. Maximum degradation rate $v s$. the ratio, nb $\mathrm{CHCl} / \mathrm{nb} \mathrm{CH}_{2}: \triangle$, LDPE thermally chlorinated $\left(90^{\circ} \mathrm{C}\right)$ in 1,1,2,2-tetrachloroethane; $\triangle$, LDPE photochlorinated $\left(20^{\circ} \mathrm{C}\right)$ in 1,1,2,2-tetrachloroethane. The percentage values represent the chlorine content by weight.

and $\beta_{I I}$ structures begin to appear, i.e., when the PVC sequences decrease. 5 Thus, the "zip" process cannot take place on a large scale. At the highest chlorine-content level (73-\% $\mathrm{Cl}_{2}$ ), the higher a CPE ratio, $\mathrm{nb} \mathrm{CHCl} / \mathrm{nb} \mathrm{CH}_{2}$, is the lower is its maximum dehydrochlorination rate (see Table III). This behavior is proof that the $\alpha_{\mathrm{II}} \quad(-\mathrm{CHCl}-\mathrm{CHCl}-\mathrm{CHCl}-)$ structure is thermodynamically more stable than the vinyl and vinylidene structures, through the free-radical dehydrochlorination mechanism. ${ }^{17-19}$

\section{Isothermal TGA Experiments}

The graphs of isothermal degradation versus time (Figure 10) and the plots of the weight loss vs. temperature (Figure 11) show a marked

Table III. Maximum dehydrochlorination of various $73-\%$ CPE samples

\begin{tabular}{|c|c|c|c|}
\hline $\begin{array}{l}\text { Chlorination } \\
\text { medium }\end{array}$ & $\begin{array}{l}\text { Chlorination } \\
\text { time, hr }\end{array}$ & $\frac{\mathrm{nb} \mathrm{CHCl}}{\mathrm{nb} \mathrm{CH}}$ & $\begin{array}{c}{\frac{\mathrm{d} W^{\mathrm{a}}}{\mathrm{d} t} \times 10^{2}}_{\mathrm{mg} / \mathrm{min}}\end{array}$ \\
\hline$\underset{20^{\circ} \mathrm{CCE}}{\mathrm{UV}}$ & 4 & 2.7 & 2.40 \\
\hline$\underset{20^{\circ} \mathrm{C}}{\mathrm{UV}}+\mathrm{CCl}_{4}$, & 4 & 3.4 & 1.68 \\
\hline$\underset{60^{\circ} \mathrm{C}}{\mathrm{UV}}+\mathrm{CCl}_{4}$ & 4 & 6 & 1.30 \\
\hline
\end{tabular}

a Maximum dehydrochlorination rate. change in the degradation process for a saturated (73-\% $\mathrm{Cl}_{2}$ ) CPE sample when the pyrolysis temperature stands in the $270-300^{\circ} \mathrm{C}$ range. According to the results of Berticat, et al.,,$^{40-22}$ a

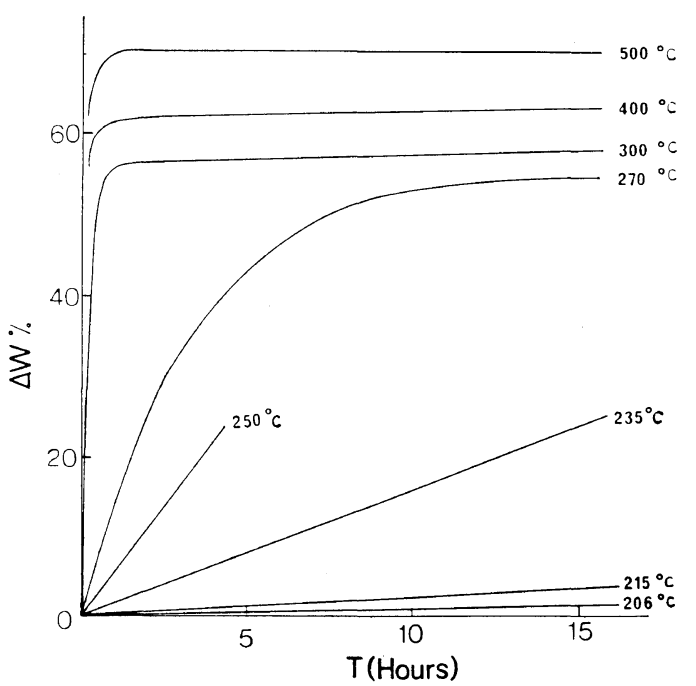

Figure 10. Isothermal TGA of the fraction of the highest number-average molecular weight of a (73\%) CPE sample produced from a 4-hr photochlorination in $\mathrm{CCl}_{4}$ at $20^{\circ} \mathrm{C}$.

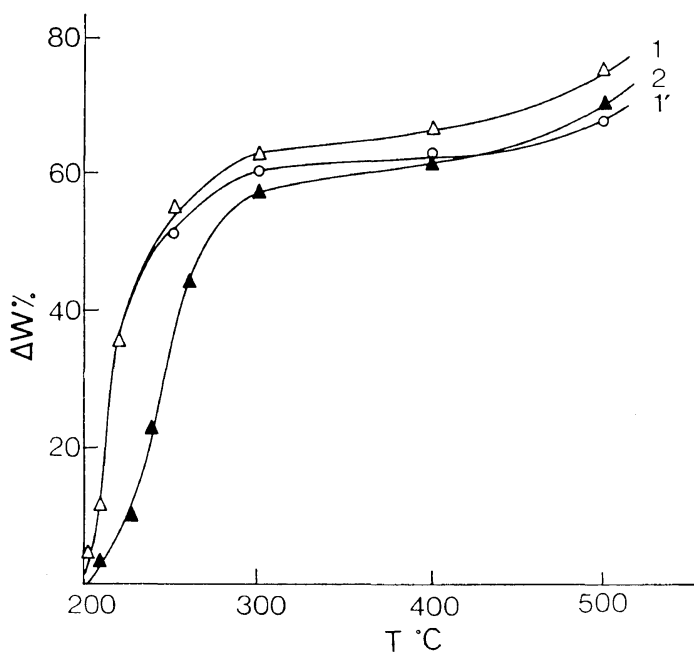

Figure 11. 1, pyrolysis in a horizontal oven, model Heraeus; 1' hydrochloric acid evolution; 2, isothermal TGA. Each (A) represents a 5-hr degradation at $235^{\circ} \mathrm{C}$. Experimental samples were the fraction of the highest number-average molecular weight of a 73-\% CPE sample produced from a $4 \mathrm{hr}$ photochlorination in $\mathrm{CCl}_{4}$ at $20^{\circ} \mathrm{C}$. 
global degradations occur during the pyrolysis process of a 73-\% CPE sample or a saturated (73\%) chlorinated PVC sample.

$\mathrm{Up}$ to about $350^{\circ} \mathrm{C}$, intra-and inter-chains dehydrochlorinations, occuring easy by the fluidity exhibited by the material between $200^{\circ} \mathrm{C}$ and $300^{\circ} \mathrm{C}$, take place. They are followed by a rearrangement of the double-bond-containing chains which give polyacenic cycles.

Between $350^{\circ} \mathrm{C}$ and $800^{\circ} \mathrm{C}$, these polyacenic cycles reticulate themselves to give a pregraphitic structure.

In order to show the influence of the molecular microstructure of the 73-\% CPE samples upon their dehydrochlorination activation energies, we will consider the first mechanism.

As can be seen in Figure 11, up to $300^{\circ} \mathrm{C}$, hydrochloric acid evolution accounts for the entire amount of the weight loss of a saturated (73-\% $\mathrm{Cl}_{2}$ ) CPE sample and up to about $270^{\circ} \mathrm{C}$ (Figure 10) the isothermal weight-loss graphs vs. times are straight lines from the intersection of the axes, which indicates that the dehydrochlorination mechanism is a zero-order one. Thus Arrhenius' plots can be drawn for a series of saturated (73\%) CPE samples (Figure 12) to calculate their global activation energies of dehydrochlorination.

The activation energies values $\left(E_{\mathrm{a}}\right)$ are listed in Table IV, along with the main characteristics of the highest number-average molecular weight

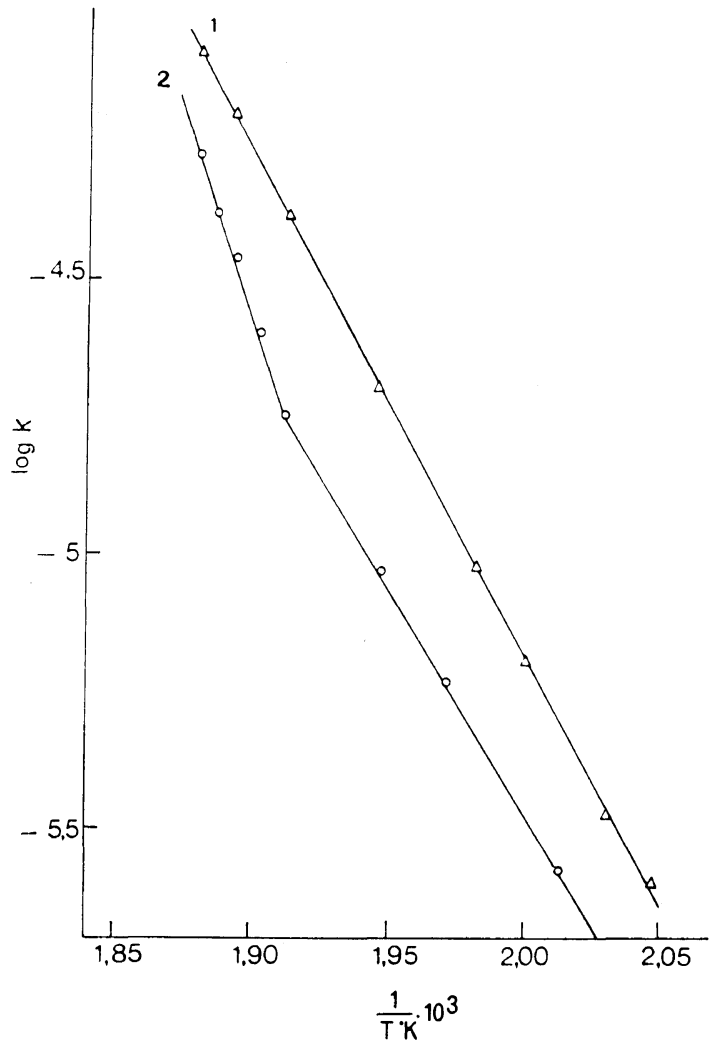

Figure 12. Arrhenius' plots: $1, \mathrm{nb} \mathrm{CHCl} / \mathrm{nb} \mathrm{CH}$ $<4 ; 2, \mathrm{nb} \mathrm{CHCl} / \mathrm{nb} \mathrm{CH}_{2} \geq 4$.

Table IV. Fractions of the highest number-average molecular weight of the 73-\% CPE samples

\begin{tabular}{|c|c|c|c|c|c|c|c|c|c|c|c|}
\hline $\begin{array}{l}\text { Initial } \\
\text { polymers }\end{array}$ & $\begin{array}{l}\text { Chlorination } \\
\text { medium }\end{array}$ & $\begin{array}{l}\text { Chlorina- } \\
\text { tion tem- } \\
\text { perature, } \\
{ }^{\circ} \mathrm{C}\end{array}$ & $\begin{array}{l}\text { Chlorina- } \\
\text { tion } \\
\text { time, hr }\end{array}$ & $\% \mathbf{H} \bar{M}_{n}^{\mathrm{a}}$ & $\begin{array}{c}\mathrm{Cl} / \mathrm{C} \\
\left(\mathrm{H} \bar{M}_{n}\right)^{\mathrm{a}}\end{array}$ & $\begin{array}{c}\overline{\mathrm{DP}}_{n} \\
\left(\mathbf{H} \bar{M}_{n}\right)^{\mathrm{a}}\end{array}$ & $\begin{array}{l}\mathrm{P}=\frac{\bar{M}_{w}}{\bar{M}_{n}} \\
\left(\mathrm{H} \bar{M}_{n}\right)^{\mathrm{a}}\end{array}$ & $\begin{array}{l}\text { Den- } \\
\text { sity }\end{array}$ & $\frac{\mathrm{nbCHCl}}{\mathrm{nbCH} \mathrm{CH}_{2}}$ & $\begin{array}{l}E_{\mathrm{a}} \\
\text { kcal }\end{array}$ & $\frac{S_{\mathrm{HH}}}{S_{\mathrm{HCl}}}=\frac{A_{615}}{A_{685}}$ \\
\hline LDPE & $\mathrm{UV}+\mathrm{CCl}_{4}$ & 20 & 4 & 75 & 1 & 537 & 2.13 & 1.6650 & 3.4 & 45 & 0.11 \\
\hline LDPE & $\mathrm{UV}+\mathrm{CCl}_{4}$ & 20 & 6 & 70 & 1 & 400 & - & 1.6758 & 3.5 & 45 & 0.28 \\
\hline LDPE & $\mathrm{UV}+\mathrm{CCl}_{4}$ & 20 & 8 & 65 & 1 & 289 & - & 1.6844 & 3.7 & 45 & 0.27 \\
\hline LDPE & $\mathrm{UV}+\mathrm{CCl}_{4}$ & 40 & 4 & - & 1 & 515 & 2.4 & 1.6720 & 4.5 & $\left.\begin{array}{l}35 \\
70\end{array}\right\}$ & 0.31 \\
\hline LDPE & $\mathrm{UV}+\mathrm{CCl}_{4}$ & 60 & 4 & 61 & 1 & 一 & 2.2 & 1.6772 & 6 & $\left.\begin{array}{l}35 \\
70\end{array}\right\}$ & 0.37 \\
\hline LDPE & $\mathrm{UV}+\mathrm{TCE}$ & 20 & 4 & 75 & 1 & 1040 & 4 & 1.6615 & 2.7 & 45 & 0 \\
\hline HDPE & $\mathrm{UV}+\mathrm{CCl}_{4}$ & 20 & 4 & 90 & 1 & 516 & 3.25 & 1.6616 & 3.4 & 45 & 0.35 \\
\hline HDPE & $\mathrm{UV}+\mathrm{CCl}_{4}$ & 20 & 6 & 86 & 1 & 505 & - & 1.6644 & 3.4 & 45 & 0.28 \\
\hline HDPE & $\mathrm{UV}+\mathrm{CCl}_{4}$ & 20 & 8 & 86 & 1 & 516 & - & 1.6640 & 3.4 & 45 & 0.26 \\
\hline HDPE & $\mathrm{UV}+\mathrm{CCl}_{4}$ & 40 & 4 & 90 & 1 & - & - & 1.6622 & 3.7 & 45 & 0.28 \\
\hline HDPE & $\mathrm{UV}+\mathrm{CCl}_{4}$ & 60 & 4 & 87 & 1 & - & 2.6 & 1.6610 & 4 & $\left.\begin{array}{l}35 \\
60\end{array}\right\}$ & 0.34 \\
\hline
\end{tabular}

a $\mathrm{H} \overline{\mathrm{M}}_{n}$, fractions of the highest number-average molecular weight of the $73-\% \mathrm{CPE}$ samples. 
$\left(\mathrm{H} \bar{M}_{n}\right)$ fractions of the 73-\% CPE samples, viz., polydispersity, $\overline{\mathrm{DP}}_{n}$, density, $\mathrm{nb} \mathrm{CHCl} / \mathrm{nb} \mathrm{CH}_{2}$, and conformation: $S_{\mathrm{HH}} / S_{\mathrm{HC}}$ or $S_{\mathrm{HH}} / S_{\mathrm{HC} 1} \cdot{ }^{6}$

One can notice that only the variations of the ratio, $\mathrm{nbCHCl} / \mathrm{nbCH}_{2}$, have an influence upon the $E_{\mathrm{a}}$ values. When this ratio value is less than 4, a saturated CPE sample has a unique global dehydrochlorination $E_{\mathrm{a}}$ of about $45 \mathrm{kcal}$. When this ratio stands between 4 and 6 there are two global dehydrochlorination $E_{\mathrm{a}}$ : the first one, about $35 \mathrm{kcal}$, rules the dehydrochlorination process up to $244-250^{\circ} \mathrm{C}$; the second, about 60 to $70 \mathrm{kcal}$, acts above this interval of temperature $\left(247-250^{\circ} \mathrm{C}\right)$ (Figure 12).

It is important to remark that, according to Oswald and Kubu, ${ }^{1}$ the $T_{\mathrm{g}}$ of polyethylene dichloride $(-\mathrm{CHCl}-\mathrm{CHCl}-\mathrm{CHCl}-)_{n}$ is at least equal to $226^{\circ} \mathrm{C}$. This estimate have been obtained by using the well-known empirical equation applied to random copolymers: ${ }^{24}$

where

$$
T_{\mathrm{g}}=\sum M_{i} T_{\mathrm{g}_{i}}
$$

$M_{i}:$ the mole fraction of the $i$ th component,

$T_{\mathrm{g}}$ : the glass temperature of the copolymer in degrees Kelvin,

$T_{\mathrm{g}_{i}}$ : the glass temperature of the homopolymer of the $i$ th component.

The value $226^{\circ} \mathrm{C}$ is indoubtedly below the real one because these authors ${ }^{1}$ have not taken into account the contribution of the vinylidene chloride and trichloroethylene units.

Moreover, Murayama and $\mathrm{Amagi}^{23}$ demonstrated that head-to-head poly(vinylidene chloride) (H-H-PVDC) is less thermally stable than head-to-tail PVC or H-H-PVC within the 200$260^{\circ} \mathrm{C}$ range.

Thus, taking into account these results ${ }^{1,23}$ and listing them together with the microstructural NMR studies, ${ }^{5,10}$ the Dupont 942 TMA experiments and the TGA results, and assuming that the dehydrochlorination process starts after the concerned structures have gone into full motion, i.e., when their main second-order transition temperature is exceeded, one can attribute the

Table Va. Branched polyethylene samples photochlorinated in 1,1,2,2-tetrachloroethane at $20^{\circ} \mathrm{C}$, Type Ia

\begin{tabular}{|c|c|c|c|c|c|c|}
\hline $\begin{array}{l}\mathrm{T}-\% \\
\mathrm{Cl}_{2}\end{array}$ & $\frac{\mathrm{nbCHCl}}{\mathrm{nbCH}}$ & $T^{\mathrm{a}},{ }^{\circ} \mathrm{C}$ & Structures responsible for the second-order transition & $T^{\mathrm{a}},{ }^{\circ} \mathrm{C}$ & $\frac{\mathrm{nbCHCl}}{\mathrm{nbCH}}$ & $\begin{array}{l}T-\% \\
\mathrm{Cl}_{2}\end{array}$ \\
\hline \multirow[t]{2}{*}{16} & \multirow[t]{2}{*}{0.111} & $36^{+b}$ & $\begin{array}{l}-\mathrm{CH}_{2}-\mathrm{CH}_{2} \text { (short vinyl sequences in amorphous phase) } \\
\mathrm{CH}_{2}-\mathrm{CH}_{2}-\end{array}$ & $33^{+b}$ & \multirow[t]{2}{*}{ - } & \multirow[t]{2}{*}{19.5} \\
\hline & & 103 & motions in partly chlorinated crystalline-phase & & & \\
\hline \multirow{3}{*}{46} & \multirow{3}{*}{0.266} & $48^{+b}$ & $\begin{array}{l}-\mathrm{CH}_{2}-\mathrm{CHCl}-\mathrm{CH}_{2}-\mathrm{CCl}_{2}-\mathrm{CH}_{2}-\mathrm{CCl}_{2}-\mathrm{CH}_{2}-\mathrm{CHCl}- \\
\mathrm{CH}_{2}-\end{array}$ & 66 & \multirow[t]{2}{*}{0.316} & \multirow[t]{2}{*}{55} \\
\hline & & 71 & $-\mathrm{CH}_{2}-\mathrm{CH}_{2}-$ long vinyl sequences $-\mathrm{CH}_{2}-\mathrm{CH}_{2}-$ & $78^{+}$ & & \\
\hline & & 90 & motions in partly chlorinated crystalline-phase & & & \\
\hline \multirow{2}{*}{60.5} & \multirow{2}{*}{0.9} & $76^{+b}$ & long vinyl sequences & & & \\
\hline & & 88 & motions in partly chlorinated crystalline-phase & & & \\
\hline \multirow{3}{*}{67.5} & & 76 & vinvl sequences & 78 & \multirow{3}{*}{1.98} & \multirow{3}{*}{68.4} \\
\hline & 1.88 & $108^{+b}$ & $\begin{array}{l}-\mathrm{CHCl}-\mathrm{CHCl}-\mathrm{CHCl}-\mathrm{CH}_{2}-\mathrm{CHCl}-\mathrm{CH}_{2}-\mathrm{CHCl}- \\
\mathrm{CHCl}-\end{array}$ & $137^{+b}$ & & \\
\hline & & 148 & $\begin{array}{l}-\mathrm{CHCl}-\mathrm{CHCl}-\mathrm{CHCl}-\mathrm{CH}_{2}-\mathrm{CCl}_{2}-\mathrm{CHCl}-\mathrm{CHCl}- \\
\mathrm{CHCl}-\end{array}$ & 150 & & \\
\hline
\end{tabular}

a Temperatures of the second-order transitions.

b The plus-marked transitions represent the glass transitions. 
B.-M. Quenum, P. Berticat, and G. Vallet

Table Vb. Branched polyethylene samples thermally chlorinated in 1,1,2,2-tetrachloroethane at $90^{\circ} \mathrm{C}$, Type $\mathrm{Ib}$

\begin{tabular}{|c|c|c|c|c|c|c|}
\hline $\begin{array}{l}T-\% \\
\mathrm{Cl}_{2}\end{array}$ & $\frac{\mathrm{nbCHCl}}{\mathrm{nbCH}_{2}}$ & $T^{\mathrm{a}},{ }^{\circ} \mathrm{C}$ & Structures responsible for the second-order transition & $T^{\mathrm{a}},{ }^{\circ} \mathrm{C}$ & $\frac{\mathrm{nbCHCl}}{\mathrm{nbCH}_{2}}$ & $\begin{array}{l}T-\% \\
\mathrm{Cl}_{2}\end{array}$ \\
\hline \multirow{3}{*}{24} & \multirow{3}{*}{$\varepsilon$} & $32+b$ & $\left(-\mathrm{CH}_{2}-\right)_{8} \mathrm{CCl}_{2}-\mathrm{CH}_{2}-\mathrm{CCl}_{2}-\mathrm{CH}_{2}\left(-\mathrm{CH}_{2}-\mathrm{CH}_{2}-\right)_{8}$ & & & \\
\hline & & 56 & motions in partly chlorinated crystalline-phase & & & \\
\hline & & & $\begin{array}{l}-\mathrm{CHCl}-\mathrm{CH}_{2}-\mathrm{CH}_{2}-\mathrm{CH}_{2}-\mathrm{CCl}_{2}-\mathrm{CH}_{2}-\mathrm{CCl}_{2}-\mathrm{CH}- \\
\mathrm{CHCl}-\end{array}$ & $-12^{+b}$ & 0.07 & 33 \\
\hline 54.5 & 0.38 & $60^{+b}$ & $\begin{array}{l}-\mathrm{CHCl}-\mathrm{CH}_{2}-\mathrm{CH}_{2}-(\text { short vinyl sequences })-\mathrm{CH}_{2}- \\
\mathrm{CH}_{2}-\mathrm{CCl}_{2}-\end{array}$ & & & \\
\hline \multirow[t]{3}{*}{61.5} & 0.44 & $55^{+\mathrm{b}}$ & $\begin{array}{l}-\mathrm{CCl}_{2}-\mathrm{CH}_{2}-\mathrm{CH}_{2}-(\text { maximum length of the vinyl } \\
\text { sequences })-\mathrm{CH}_{2}-\mathrm{CH}_{2}-\mathrm{CHCl}\end{array}$ & 58 & \multirow{3}{*}{1.31} & \multirow{3}{*}{65} \\
\hline & & & long vinyl sequences & $70^{+b}$ & & \\
\hline & & & $-\mathrm{CHCl}-\mathrm{CHCl}-\mathrm{CH}_{2}-\mathrm{CHCl}-\mathrm{CH}_{2}-\mathrm{CHCl}-\mathrm{CHCl}-$ & 102 & & \\
\hline
\end{tabular}

a Temperatures of the second-order transition.

b The plus-marked transitions represent the glass transitions.

Table Vc. Linear polyethylene samples thermally chlorinated in 1,1,2,2-tetrachloroethane at $110^{\circ} \mathrm{C}$, Type Ic

\begin{tabular}{|c|c|c|c|c|c|c|}
\hline $\begin{array}{l}T-\% \\
\mathrm{Cl}_{2}\end{array}$ & $\frac{\mathrm{nbCHCl}}{\mathrm{nbCH}_{2}}$ & $T^{\mathrm{a}},{ }^{\circ} \mathrm{C}$ & Structures responsible for the second-order transitions & $T^{\mathrm{a}},{ }^{\circ} \mathrm{C}$ & $\frac{\mathrm{nbCHCl}}{\mathrm{nbCH}}$ & $\begin{array}{l}T-\% \\
\mathrm{Cl}_{2}\end{array}$ \\
\hline \multirow[t]{3}{*}{6} & \multirow[t]{2}{*}{$\varepsilon$} & $10^{+b}$ & $\begin{array}{l}\left(-\mathrm{CH}_{2}-\mathrm{CH}_{2}-\right)_{8}-\mathrm{CCl}_{2}-\mathrm{CH}_{2}-\mathrm{CH}_{2}-\mathrm{CCl}_{2}-\left(\mathrm{CH}_{2}-\right. \\
\left.\mathrm{CH}_{2}-\right)_{8}\end{array}$ & & & \\
\hline & & 104 & motions in partly chlorinated crystalline-phase & & & \\
\hline & & & 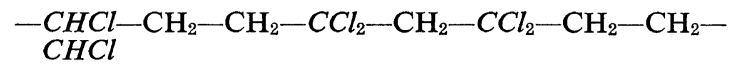 & $0^{+b}$ & 0.114 & 41 \\
\hline \multirow{4}{*}{56} & \multirow{3}{*}{0.483} & 52 & $\begin{array}{l}-\mathrm{CCl}_{2}-\mathrm{CH}_{2}-\mathrm{CH}_{2}-(\text { short vinyl sequences })-\mathrm{CH}_{2}- \\
\quad \mathrm{CHCl}-\end{array}$ & & & \\
\hline & & $68^{+b}$ & long vinyl sequences & $76^{+b}$ & \multirow{3}{*}{1.27} & \multirow{3}{*}{61.7} \\
\hline & & 90 & $\begin{array}{l}-\mathrm{CHCl}-\mathrm{CHCl}-(\text { short vinyl sequences })-\mathrm{CHCl}- \\
\mathrm{CHCl}-\end{array}$ & 94 & & \\
\hline & & & $\underset{\mathrm{CHCl}}{-\mathrm{CHCl}-\mathrm{CHCl}-\mathrm{CHCl}-\mathrm{CH}_{2}-\mathrm{CHCl}-\mathrm{CHCl}-\mathrm{CHCl}-}$ & 130 & & \\
\hline \multirow{3}{*}{67} & \multirow{3}{*}{2.66} & 75 & vinyl sequences & $80^{+b}$ & \multirow{3}{*}{1.98} & \multirow{3}{*}{64} \\
\hline & & $160^{+b}$ & $-\underset{\mathrm{CHCl}-\mathrm{CHCl}-\mathrm{CHCl}-\mathrm{CHCl}-\mathrm{CH}_{2}-\mathrm{CHCl}-\mathrm{CH}_{2}-\mathrm{CHCl}-}{\mathrm{CHCl}}$ & 128 & & \\
\hline & & 176 & $\begin{array}{l}-\mathrm{CHCl}-\mathrm{CHCl}-\mathrm{CHCl}-\mathrm{CHCl}-\mathrm{CH}_{2}-\mathrm{CCl}_{2}-\mathrm{CHCl}- \\
\mathrm{CHCl}-\mathrm{CHCl}-\end{array}$ & 160 & & \\
\hline
\end{tabular}

a Temperatures of the second-order transitions.

b The plus-marked transitions represent the glass transitions. 
35-kcal and 45-kcal $E_{\mathrm{a}}$ to the global dehydrochlorination activation energy of the sequences (type A) below:

$$
\begin{array}{rlr}
\mathrm{Aa}- & \mathrm{CHCl}-\mathrm{CHCl}-\mathrm{CHCl}-\mathrm{CHCl}-\mathrm{CH}_{2}- \\
& \mathrm{CHCl}-\mathrm{CH}_{2}-\mathrm{CCl}_{2}- & 45 \mathrm{kcal} \\
\mathrm{Aa}^{\prime}- & \mathrm{CHCl}-\mathrm{CHCl}-\mathrm{CH}_{2}-\mathrm{CCl}_{2}-\mathrm{CH}_{2}- \\
& \mathrm{CCl}_{2}-\mathrm{CH}_{2}-\mathrm{CHCl}- & 35 \mathrm{kcal}
\end{array}
$$

and the 60-kcal and 70-kcal $E_{\mathrm{a}}$ to sequences (type B) below:

$$
\begin{array}{rrr}
\mathrm{Bb}-\mathrm{CHCl}-\mathrm{CHCl}-\mathrm{CCl}_{2}-\mathrm{CH}_{2}-\mathrm{CHCl}- \\
& \mathrm{CH}_{2}-\mathrm{CCl}_{2}-\mathrm{CHCl}- & 60 \mathrm{kcal} \\
\mathrm{Bb}^{\prime} & -\mathrm{CHCl}-\mathrm{CHCl}-\mathrm{CHCl}-\mathrm{CHCl}-\mathrm{CH}_{2}-. \\
& \mathrm{CCl}_{2}-\mathrm{CHCl}-\mathrm{CHCl}- & 70 \mathrm{kcal}
\end{array}
$$

If we consider that the initiation rate rules the dehydrochlorination rate, the italic-written segments of the above sequences (types $\mathrm{A}$ and B) can be regarded as the initiation sites of the degradation process.

\section{CONCLUSION}

The isothermal TGA results confirm the assumptions made during the discussion about the second-order transitions, viz., the temperatures at which the sequences of type $\mathrm{A}$ go into motion are lower than those of the sequence of type B.

We can now assign the different second-order transitions, observed with the Dupont 942 TMA experiments, to the molecular structures which can be regarded as responsible for them (Tables V). A portion of these different structures have been written in italic, in order to point out their particular contribution to the second-order transition. When a CPE sample has many second-order transitions, the responsible structures can belong either to the same polymeric chain; and therefore they are each from widely separated other; or they can belong to distinct polymeric chains. The values of the ratio, $\mathrm{nbCHCl} / \mathrm{nbCH}_{2}$, in Tables $\mathrm{V}$ give a rough estimate of the chlorinated chains' length.

Our previous study ${ }^{10}$ dealing with the dynamic mechanical properties of the CPE samples studied here confirms these structural attributions.

\section{REFERENCES}

1. H. J. Oswald and E. T. Kubu, SPE, Trans., 3, 168 (1963).

2. Vaïno A. Erä and J. Johan Lindberg, J. Polym. Sci., Part A-2, 10937 (1972).

3. Ismat. A. Abu Isa, ibid., Part $A-2,10,881$ (1972).

4. N. Saglio, P. Berticat, and G. Vallet, J. Appl. Polym. Sci., 16, 2991 (1972).

5. B. M. Quenum, P. Berticat, and G. Vallet, Polymer J., 7, 287 (1975).

6. B. M. Quenum, P. Berticat, and G. Vallet, ibid., 7, 277 (1975).

7. B. M. Quenum, P. Berticat, and Q. T. Pham, Eur. Polym. J., 7, 1527 (1971).

8. B. M. Quenum, P. Berticat, and Q. T. Pham, ibid., 9, 777 (1973).

9. G. Humbert, B. M. Quenum, P. Berticat, Q. T. Pham, and G. Vallet, Makromol. Chem., 175, 1597 (1974).

10. G. Humbert, B. M. Quenum, P. Berticat, and G. Vallet, ibid., 175, 1611 (1974).

11. T. F. Schatski, J. Polym. Sci., 57, 496 (1962).

12. R. F. Boyer, Rubber Chem. Tech., 36, 1303 (1963).

13. W. W. Wendlandt, "Thermal Methods of Analysis, Interscience, New York, N.Y., 1964.

14. A. Guyot and M. Bert, J. Appl. Polym. Sci., 17, 753 (1973).

15. J. D. Hoffman and B. M. Axilrod, J. Res. Nat. Bur. Stds, 54, 357, RP 2598 (1955).

16. J. Millan, M. Caransa, and J. Gusman, IUPAC Symposium on Macromolecules, Helsinki 1972, Preprint IV, 21, Vol. 5.

17. E. J. Arlman, J. Polym., Sci., 12, 543 (1959).

18. B. Baum and L. H. Wartman, ibid., 28, 537 (1968).

19. B. Baum and M. Thallmaier, Kunstoffe, 56, 80 (1966).

20. P. Berticat, J. J. Bejat, and G. Vallet, J. Chim. Phys., 67, 164 (1970).

21. P. Berticat, J. J. Bejat, ibid., 67, 170 (1970).

22. P. Berticat, J. J. Bejat, J.F. May, and G. Vallet, ibid., 67, 176 (1970).

23. N. Murayama and Y. Amagi, Polym. Letters, 4, 119 (1966).

24. A. V. Tobolsky, "Properties and Structure of Polymers, Wiley and Sons, New York, N.Y., 1960. 